\section{Unexpected Cat Allergy in Infants with Persistent Atopic Dermatitis}

\section{Serdar Al ${ }^{\oplus}$ Suna Asilsoy $\odot$ Özden Anal $\odot$ Dilek Tezcan $\odot$ \\ Seda Şirin Köse $\odot$ Gizem Atakul ๑ Özge Atay $\odot$ Özge Kangallı ๑ Nevin Uzuner $\odot$ Özkan Karaman $\odot$} Persistan Atopik Dermatitli Infantlarda Beklenmeyen
Kedi Alerjisi

\begin{abstract}
Atopic dermatitis is a chronic, recurrent inflammatory skin disease usually caused by genetic predisposition, immune dysregulation, epidermal barrier dysfunction and interaction of environmental factors. Atopic dermatitis is part of atopic march and is often accompanied by food allergy. Aeroallergenic sensitization at early age is not an expected finding. Here, we present five cases with moderate-severe atopic dermatitis during infancy, in whom food allergy was detected and the symptoms improved only partially despite elimination and treatment.

Sensitization was investigated in patients with a history of intense exposure to cats by specific IgE and skin prick test in infants with atopic dermatitis who had food allergy and persistant findings.

Egg allergy was detected in four of the cases, wheat allergy in one. Cat allergy was present in all. Elimination diet was started in all cases. When exposure to cats was reduced, a marked improvement in the findings of atopic dermatitis was observed in all cases.

Allergic diseases are increasing day by day. Unexpected aeroallergenic sensitization is now more common in the early stages of life. Allergic patients, regardless of age, should be questioned in detail for aeroallergen exposure. If it is detected; necessary preventive measures should be taken.
\end{abstract}

Keywords: Atopic dermatitis, infant, cat allergy, skin prick test

Öz

Atopik dermatit, genellikle genetik yatkınlık, immun disregülasyon, epidermal bariyer işlev bozukluğu ve çevresel faktörler etkileşiminden kaynaklanan kronik, tekrarlayıcı bir enflamatuar deri hastalığıdır. Atopik dermatit atopik yürüyüşün bir parçasıdır ve sıklıkla gıda alerjisi eşlik eder. Erken yaşta aeroerojenik duyarIılaşma beklenen bir bulgu değildir. Burada, bebeklik döneminde orta derecede şiddetli atopik dermatiti olan, gıda alerjisinin tespit edildiği ve semptomların eliminasyon ve tedaviye rağmen sadece kısmen düzeldiği beş olguyu sunuyoruz.

Gıda alerjisi ve kalıcı atopik dermatit bulguları olan bebeklerde, kedilere yoğun maruzuyet öyküsü olan hastalarda spesifik IgE ve cilt prik testi ile duyarlılı araştıııldı.

Olguların dördünde yumurta alerjisi, birinde buğday alerjisi saptandı. Tümünde kedi duyarlılığı mevcuttu. Tüm vakalarda eliminasyon diyetine başlandı. Tüm vakalarda kedi maruziyeti azaltıldığında, atopik dermatit bulgularında belirgin bir düzelme gözlendi.

Alerjik hastalıklar her geçen gün artmaktadır. Beklenmedik aeroalerjenik duyarlılaşma artık yaşamın erken evrelerinde daha yaygındır. Alerjik hastalar, yaşa bakılmaksızın, aeroalerjene maruz kalma açısından ayrıntılı olarak sorgulanmalıdır. Duyarlaşma saptanırsa gerekli önlemler alınmalıdır.
Received: 26.08 .2020

Accepted: 23.12 .2020

Published Online: 03.08 .2021

Cite as: Al S, Asilsoy S, Anal Ö, et al. Unexpected cat allergy in infants with persistent atopic dermatitis. İzmir Dr. Behçet Uz Çocuk Hast. Dergisi. 2021;11(2):210-4.

Serdar Al

Dokuz Eylül Üniversitesi Tıp Fakültesi, Çocuk Alerji ve Klinik İmmunoloji Bilim Dalı, İzmir, Türkiye drserdaral@gmail.com ORCID: 0000-0002-4846-6761

Suna Asilsoy 0000-0002-4235-0995 Özden Anal 0000-0003-3888-2689

Dilek Tezcan 0000-0002-0124-9268

Seda Şirin Köse 0000-0002-9300-5999

Gizem Atakul 0000-0002-3508-1360

Özge Atay 0000-0002-7673-3601

Özge Kangallı 0000-0003-3393-489X

Nevin Uzuner 0000-0001-8862-7825

Özkan Karaman 0000-0002-5675-3808 Dokuz Eylül Üniversitesi Tıp Fakültesi, Çocuk Alerji ve Klinik Immunoloji Bilim Dalı, Izmir, Türkiye

Anahtar kelimeler: Atopik dermatit, infant, kedi alerjisi, deri prik testi

\section{INTRODUCTION}

Atopic dermatitis (AD) is a chronic, recurrent inflammatory skin disease usually caused by genetic predisposition, immune dysregulation, epidermal barrier dysfunction and interaction of environmental factors. Allergic rhinitis and asthma may occur in children with $A D$ during infancy and this condition is called 'atopic march ${ }^{(1)}$. AD usually develops in early childhood and is the first step of atopic march before

(c) Copyright İzmir Dr. Behçet Uz Children's Hospital. This journal published by Logos Medical Publishing.

Licenced by Creative Commons 4.0 International (CC BY) 
respiratory allergies. The incidence of other allergic diseases increases in patients with $A D$ and many of their family members have atopy ${ }^{(2)}$. In these patients, food allergy, which is more common in infancy and early childhood, gradually decreases with age, but sensitivity to aeroallergens increases after the age of three while sensitization to aeroallergens early in life (first two years) is not an expected finding3. The most common aeroallergens are mites, animal dander, pollen, mold and cockroaches ${ }^{(2)}$.

Pet owning and sensitivities to pet allergens are increasing all over the world. Among pets, the cat is important due to its allergic properties. There are controversial data on early cat exposure. While some studies suggest that exposure reduces risk of asthma, others defend the opposite ${ }^{(4,5)}$. Here, we present five cases with moderate-severe atopic dermatitis during infancy, in whom food allergy was detected and the symptoms improved only partially, despite elimination and treatment. History of exposure to cats during and after pregnancy was revealed, and cat allergies were detected with skin prick test during infancy.

\section{Case 1:}

Four month-old girl was admitted with symptoms of atopic dermatitis that started when she was 2 months old. Pre and postnatal history was unremarkable. She was only fed with breast milk. There was no cat exposure at home. She often had a visit to an aunt who owned cats at home. On examination, she had eczematous rash on the cheeks. SCORAD ("SCORing Atopic Dermatitis") score was 38. Laboratory findings were as follows, peripheral blood eosinophil ocunts: $5.3 \%\left(500 / \mathrm{mm}^{3}\right)$, total IgE: 12.2 $\mathrm{IU} / \mathrm{mL}$, specific IgE egg white: $14.5 \mathrm{kU} / \mathrm{l}$, specific IgE egg yolk: $1.3 \mathrm{kU} / \mathrm{l}$, specific IgE FX5 (food mixture): $6.15 \mathrm{kU} / \mathrm{l}$. The skin prick test was performed at 4 months of age that revealed formation of wheal and flare of $4 \mathrm{~mm}$ with egg white, and $2 \mathrm{~mm}$ with egg yolk. Egg elimination diet and local treatment achieved partial improvement, but atopic findings occasionally increased. The results of skin prick test performed at the age of 9 months to evaluate aeroallergenic sensitivity to house dust and cat were as follows: cat: $4 \mathrm{~mm}$; egg whites: $11 \mathrm{~mm}$, and egg yolk: $2 \mathrm{~mm}$. In addition to treatment, avoidance of cat exposure was recommended.

\section{Case 2:}

A 7-month-old male patient was admitted with complaints of $A D$ that started 2 weeks before. In the prenatal period, the mother owned a cat at home until the last trimester of pregnancy, and she sent the cat to the grandmother's house during her last trimester but paid frequent visits to her. SCORAD score was 53. Laboratory findings revealed peripheral blood eosinophil count: $2.1 \%\left(200 / \mathrm{mm}^{3}\right)$, total IgE: $17.3 \mathrm{IU} / \mathrm{mL}$, specific IgE egg white: $1.37 \mathrm{kU} / \mathrm{l}$, specific IgE FX5 (food mix): $0.515 \mathrm{kU} / \mathrm{l}$. In skin prick test, cat: $4 \mathrm{~mm}$, egg whites: $5 \mathrm{~mm}$ were detected. The patient's complaints were partially relieved by the elimination of the egg from his diet, but improved significantly following eliminating cat exposure.

\section{Case 3:}

A 3-month-old male patient presented with the complaint of $A D$, that started at 2 weeks of age. His family had two cats and one dog at home during and after pregnancy. SCORAD score was 46. Laboratory findings were as follows: peripheral blood eosinophil $2.2 \%\left(100 / \mathrm{mm}^{3}\right)$, total IgE: $9.74 \mathrm{IU} / \mathrm{mL}$, specific IgE wheat: $0.29 \mathrm{kU} / \mathrm{l}$, specific IgE FX5 (food mix): $<0.10$ $\mathrm{kU} / \mathrm{l}$. The patient was recommended to be at follow up in that period. Tests performed when he was 9 months old revealed total IgE: $149 \mathrm{IU} / \mathrm{mL}$, specific IgE wheat: $2.79 \mathrm{kU} / \mathrm{l}$, specific IgE FX5 (food mixture): $18.2 \mathrm{kU} / \mathrm{l}$, specific IgE cat: $34.2 \mathrm{kU} / \mathrm{l}$. Skin prick test results were: cat: $5 \mathrm{~mm}$ wheat flour: $5 \mathrm{~mm}$. Wheat was eliminated from the diet of the infant. However, his symptoms improved partially despite treatment, as cat exposure continued at home.

\section{Case 4:}

A-3-month-old girl was admitted with symptoms of atopic dermatitis, restlessness and mucus in stool that started when she was 2 months old. They had a cat at home during and after pregnancy. Pre and postnatal history was unremarkable except cat exposure. SCORAD score was 48 . Laboratory findings 
were as follows: peripheral blood eosinophil 7.3\% $\left(600 / \mathrm{mm}^{3}\right)$, total IgE: $68.9 \mathrm{IU} / \mathrm{mL}$, spesific IgE wheat: $<0.35 \mathrm{kU} / \mathrm{l}$, spesific IgE egg white: $<0.35 \mathrm{kU} / \mathrm{l}$, spesific IgE egg yolk: $<0.35 \mathrm{kU} / \mathrm{l}$, spesific IgE cow milk: $<0.35$ $\mathrm{kU} / \mathrm{I}$, spesific IgE cat: $1.66 \mathrm{kU} / \mathrm{l}$. In skin prick test cat:4 $\mathrm{mm}$ egg white:3 $\mathrm{mm}$, egg yolk:3 $\mathrm{mm}$ was detected. Egg was eliminated from the diet of the infant. Avoidance of cat exposure was recommended and then symptoms decreased.

\section{Case 5:}

A-4-month- old male patient was admitted with complaints of $A D$ that started when he was 1 month old. His father had allergic rhinitis and metal allergy. SCORAD score was 38 . Family had a cat at home during and after pregnancy. Laboratory findings were as follows: peripheral blood eosinophil $2.1 \%$ $\left(100 / \mathrm{mm}^{3}\right)$, total IgE: $8.93 \mathrm{IU} / \mathrm{mL}$, spesific IgE FX5 (food mix): $3.20 \mathrm{kU} / \mathrm{l}$, spesific IgE egg white: 5.68 $\mathrm{kU} / \mathrm{l}$, spesific IgE cow milk: $2.29 \mathrm{kU} / \mathrm{l}$. In skin prick test cat:3 mm egg white:12 mm, egg yolk:2 mm, cow's milk:8 mm was detected. Egg and milk were eliminated from the diet of the infant. Eliminating cat exposure was recommended and then symptoms decreased.

\section{DISCUSSION}

Atopic dermatitis affects approximately $20 \%$ of children and $10 \%$ of adults in developed countries 6 with a still increasing frequency ${ }^{(7)}$. Industrialization and western life style are thought to facilitate the onset of $A D$ in predisposed individuals ${ }^{\left({ }^{8}\right)}$. Other allergic diseases are more common in these patients than in the general population. It is considered as a risk factor for asthma and allergic rhinitis especially in childhood and recommended that patients with moderate-severe and treatment-resistant AD should be evaluated for allergy. In these patients, susceptibility to both food and aeroallergens can be triggered. Although the most common triggering factor is food allergy in childhood, aeroallergen sensitivity may also be important. Our patients with a history of cat exposure in the early period presented with $A D$ findings during the infancy and food sensitivity was determined during evaluation of allergy. Allergen food was eliminated from the diet. The patients whose symptoms partially regressed despite treatment were evaluated for cat sensitivity, although there was no expected finding under one year due to history of cat exposure. Exposure should be avoided

Table 1. Characteristics of the patients.

\begin{tabular}{|c|c|c|c|c|c|}
\hline & Case 1 & Case 2 & Case 3 & Case 4 & Case 5 \\
\hline Age (month) & 4 & 7.5 & 3.5 & 3.5 & 4 \\
\hline Gender (F,M) & $\mathrm{F}$ & $\mathrm{M}$ & $\mathrm{M}$ & $\mathrm{F}$ & $\mathrm{M}$ \\
\hline Cat exposure & often & often & continuous & continuous & continuous \\
\hline SCORAD & 38 & 53 & 46 & 48 & 38 \\
\hline Blood eosinophil $\left(\%, \mathrm{n} / \mathrm{mm}^{3}\right)$ & $5.3 \%(500)$ & $2.1 \%(200)$ & $2.2 \%(200)$ & $2.1 \%(100)$ & $7.3 \%(600)$ \\
\hline Total IgE (IU/mI) & 12.2 & 17.3 & 179 & 8.93 & 68.9 \\
\hline \multicolumn{6}{|l|}{ Specific IgE (kU/L) } \\
\hline Egg white & 14.5 & 1.37 & - & $<0.35$ & 5.68 \\
\hline Egg yolk & 1.3 & - & - & $<0.35$ & - \\
\hline Cow milk & - & - & - & $<0.35$ & 2.29 \\
\hline FX5 (food mix) & 6.15 & 0.515 & 18.2 & $<0.35$ & 3.2 \\
\hline Wheat & - & - & 2.79 & $<0.35$ & - \\
\hline Cat & - & - & 34.2 & 1.66 & - \\
\hline \multicolumn{6}{|l|}{ Skin prick test (mm) } \\
\hline Egg white & 11 & 5 & - & 3 & 12 \\
\hline Egg yolk & 2 & - & - & 3 & 2 \\
\hline Cow milk & - & - & - & - & 8 \\
\hline Cat & 4 & 4 & 5 & 4 & 3 \\
\hline Wheat & - & - & 5 & - & - \\
\hline Ongoing cat exposure & no & no & yes & no & no \\
\hline Food elimination & yes & yes & yes & yes & yes \\
\hline Clinical improvement & yes & yes & partially & yes & yes \\
\hline
\end{tabular}


in cases with cat sensitivity detected in their skin prick tests and SplgE measurements. A significant regression was found in the $A D$ findings of our cases by eliminating the exposure.

The diagnosis of food allergy is made by foodspecific IgE measurement, positive skin prick test, elimination of suspected food from diet and food challenge or double-blind placebo-controlled food challenge (DBPCFC), which is considered the most reliable method. The prevalence rates of food allergy confirmed by the food loading test (DBPCFC) in infants with $A D$ ranges from $33 \%$ to $63 \%{ }^{(8,9)}$. As aeroallergen susceptibility, association between $A D$ and mite allergy was emphasized. However, pet allergies have been increasing in recent years. As the level of social development increases, pet owning rates increase. Cat ownership has increased by up to $57 \%$ in some countries. In our country, the cat ownership rate is determined as $15 \%{ }^{(10)}$. In developed countries, $10-15 \%$ of the population has a pet allergy. Cat allergy is one of the most common pet allergies. Recently, eight cat allergens namely, Fel d1-d8 have been identified. The most common sensitization was determined against Fel d1. Sensitization was determined using saliva, danders and urine-dispersed allergens. Cat allergens were associated with eczema, allergic rhinitis, and asthma. The presence of cat exposure at an early age (first year of life) was found to be a risk factor for asthma, rhinoconjunctivitis and eczema symptoms in children aged 6-7 years ${ }^{(5)}$. A Swedish study found that cat exposure at an early age increases the risk of cat sensitization in skin prick testing ${ }^{(11)}$. Another study found a high risk of eczema in children with cat exposure at home under one year of age ${ }^{(12)}$. Cat sensitivity may begin at an early age and accompany food allergy. A significant relationship was found between disease severity and sensitivity to pet dander in children with AD under 2 years of age ${ }^{(13)}$. Current guidelines recommend avoidance of exposure to these allergens for patients with animal dander allergy ${ }^{(14,15)}$.

Food allergy was determined in our cases, but although the food the patients were sensitive to was eliminated from the diet, symptoms of atopic dermatitis improved only partially. The symptoms were found to be significantly improved when cat exposure was prevented.

\section{CONCLUSION}

As the level of social development increases, the rate of pet owning is increased in different cultures. Increased pet exposure may cause allergies at a younger age. Allergic patients, regardless of age, should be questioned in detail for household pet exposure. If there is any, allergy should be detected as early as possible and protective measures should be taken in case of need.

Conflict of Interest: The authors have no conflicts of interest to declare.

Informed Consent: Written informed consent was obtained from the parent of the patient who participated in this study.

\section{REFERENCES}

1. Johansson SGO, Bieber T, Dahl R, et al. Revised nomenclature for allergy for global use: Report of the Nomenclature Review Committee of the World Allergy Organization, October 2003. J Allergy Clin Immunol. 2004;113(5):832-6. https://doi.org/10.1016/j.jaci.2003.12.591

2. Ertam I, Su Ö, Alper S, et al. The Turkish guideline for the diagnosis and management of atopic dermatitis-2018. Turkderm Turkish Arch Dermatology Venereol. 2018;52(1):623.

https://doi.org/10.4274/turkderm.87143

3. Seo E, Yoon J, Jung S, Lee J, Lee BH, Yu J. Phenotypes of atopic dermatitis identified by cluster analysis in early childhood. J Dermatol. 2019;46(2):117-23. https://doi.org/10.1111/1346-8138.14714

4. Stokholm J, Chawes BL, Vissing N, Bønnelykke K, Bisgaard H. Cat exposure in early life decreases asthma risk from the $17 q 21$ high-risk variant. J Allergy Clin Immunol. 2018;141(5):1598-1606.

https://doi.org/10.1016/j.jaci.2017.07.044

5. Brunekreef B, Von Mutius E, Wong G, Odhiambo J, GarcíaMarcos L, Foliaki S. Exposure to cats and dogs, and symptoms of asthma, rhinoconjunctivitis, and eczema. Epidemiology. 2012;23(5):742-50.

https://doi.org/10.1097/EDE.0b013e318261f040

6. Flohr C, Mann J. New insights into the epidemiology of childhood atopic dermatitis. Allergy Eur J Allergy Clin Immunol. 2014;69(1):3-16. https://doi.org/10.1111/all.12270

7. Deckers IAG, McLean S, Linssen S, Mommers M, van Schayck $\mathrm{CP}$, Sheikh A. Investigating international time trends in the incidence and prevalence of atopic eczema 1990-2010: A systematic review of epidemiological studies. PLoS One. 2012;7(7). 
https://doi.org/10.1371/journal.pone.0039803

8. Eigenmann PA, Calza AM. Diagnosis of IgE-mediated food allergy among Swiss children with atopic dermatitis. Pediatr Allergy Immunol. 2000;11(2):95-100.

https://doi.org/10.1034/j.1399-3038.2000.00071.x

9. Pajno GB, Fernandez-Rivas M, Arasi S, et al. EAACI Guidelines on allergen immunotherapy: IgE-mediated food allergy. Allergy Eur J Allergy Clin Immunol. 2018;73(4):799-815. https://doi.org/10.1111/all.13319

10. GfK. Global pet ownership survey. Pet ownership. Published 2016. https://www.petfoodindustry.com/articles/5845infographic-most-of-world-owns-pets-dogs-are-tops

11. Sandin A, Björkstén B, Bråbäck L. Development of atopy and wheezing symptoms in relation to heredity and early pet keeping in a Swedish birth cohort. Pediatr Allergy Immunol. 2004;15(4):316-22. https://doi.org/10.1111/j.1399-3038.2004.00166.x

12. Epstein TG, Bernstein DI, Levin L, et al. Opposing Effects of Cat and Dog Ownership and Allergic Sensitization on Eczema in an Atopic Birth Cohort. J Pediatr. 2016;158(2):265-71. https://doi.org/10.1016/j.jpeds.2010.07.026

13. Cid BJ, Perez-Mateluna G, Iturriaga $C$, et al. Is there an association between indoor allergens and the severity of atopic dermatitis? Int J Dermatol. 2019;58(4):433-9. https://doi.org/10.1111/ijd.14281

14. Broek JL, Bousquet J, Baena-Cagnani CE, et al. Allergic Rhinitis and its Impact on Asthma (ARIA) guidelines: 2010 Revision. J Allergy Clin Immunol. 2010;126(3):466-76. https://doi.org/10.1016/j.jaci.2010.06.047

15. Weidinger S, Beck LA, Bieber T, Kabashima K, Irvine AD. Atopic dermatitis. Nat Rev Dis Prim. 2018;4(1). https://doi.org/10.1038/s41572-018-0001-z 